\title{
Aligning Corporate Governance with Enterprise Risk Management Adoption in the Nigerian Deposit Money Banks
}

\author{
Ishaya John Dabari ${ }^{*}$, Sini Fave Kwaji ${ }^{1}$ and Mohamad Zulkurnai Ghazali² \\ ${ }^{1}$ Department of Accountancy, School of Management and Information Technology Modibbo Adama \\ University of Technology, Yola, Adamawa State, Nigeria \\ 2 Tunku Puteri Intan Safinaz School of Accountancy, College of Business, Universiti Utara Malaysia, \\ Malaysia
}

\begin{abstract}
The alarming rate of corporate failures as seen universally has necessitated this study apparently; the failures have known no boundary as it cuts across both the very big organizations and the very small corporate entities especially financial industries. The objective of this study is to align corporate governance (CG) with Enterprise Risk Management (ERM) adoption in the Nigeria Deposit Money banks (DMBs). The study adopted cross-sectional research design, survey method and questionnaire technique to collect data in 21 Nigerian DMBs. A total of 722 questionnaires were distributed, out of which 435 were found usable for further analysis. The research adopted Structural Equation Modeling in Stata for the data analysis. Empirical evidence suggests that internal audit effectiveness, human resource competency and top management commitment were positively significant. This implies that there is a significant positive relationship between CG and ERM adoption. Conclusively, the study has provided insightful results for the banking industry, regulators, practitioners and academia that will potentially assist in policy formulation, implementation and evaluation. Thus, a clarion calls for all the stakeholders in the industry to guarantee broad implementation of ERM in all the banks in compliance with the CBN Code of corporate governance.
\end{abstract}

Keywords: Enterprise risk management, corporate governance, ERM adoption; Nigerian banks

JEL Classification Code: M40, M41, M49, G20, G21, G24, G28, G32, G34

Paper Type: Research

\section{INTRODUCTION}

Given the complexities of the banking environment, the effort to deal with risk exposures has become crucial to their survival. Companies continue to face heightened instability

\footnotetext{
*Corresponding author: E-mail: veedabari@gmail.com
} 
from the effect of globalisation, deregulations, and intense competitions. As such, the failure of banks to be proactive in risk assessment, mitigation and control had resultant effect of poor corporate governance and ultimate failure in the past. Moreover, the majority of corporate bodies lacked the active strategies for identifying new business opportunities. The fact remains unchanged that there is the need for countries to have sound, resilient banking systems with good corporate governance (Afolabi \& Dare, 2015). This will strengthen and upgrade the institution to survive in an increasingly open environment (Fadun, 2013; Kashif, 2008).

Enterprise Risk Management (ERM) redefines the value proposition of risk management by elevating its focus from tactical to the strategic. Enterprise Risk Management is about designing and implementing capabilities for managing the risks that matter. The higher the gaps in the current state of ERM practices and the expected future state of the banks risk management capabilities, the higher the need for ERM infrastructure to facilitate the advancement of risk management capabilities over time (Ahmad, 2014).

According to Afolabi and Dare (2015) study, several events are therefore responsible for the heightened interest in corporate governance especially in both developed and developing countries. The subject of corporate governance leapt to global business limelight from relative obscurity after a string of collapses of high profile companies. Ahmad (2014) suggests that ERM is a critical part of the corporate governance system. The Code of Corporate Governance apparently spelt out the guidelines for the Board of Directors to adequately perform their duties concerning monitoring role, even using internal or external monitoring mechanisms such as auditors in line with Agency theory (Dabari \& Saidin, 2016). Competency level of the Board of Directors and top management will enable them to exploit opportunities and minimise threats associated with risks for the benefit of the bank particularly enhancing competitive advantage. The assurance provided by the internal auditors to the stakeholders is a crucial requirement of ISO 31000 which provides specific approaches and guidance on ERM process. Therefore, internal audit has to update its role and responsibilities to support continuous improvement of ERM implementation.

In developing economies, the banking sector among other sectors has also witnessed several cases of collapses, some of which include the Alpha Merchant Bank Ltd, Savannah Bank Plc, Societe Generale Bank Ltd (all in Nigeria), The Continental Bank of Kenya Ltd, Capital Finance Ltd, Consolidated Bank of Kenya Ltd and Trust Bank of Kenya among others (Akpan, 2007). In Nigeria, the issue of corporate governance has been given the front burner status by all sectors of the economy by the issuance of Codes of corporate governance by Security and Exchange Commission (SEC) and Central Bank of Nigeria (CBN). Jensen and Meckling (1976) acknowledged that the principal-agent theory which was also adopted in this study served as the starting point for any debate on the issue of corporate governance. Some corporate governance mechanisms have been proposed to ameliorate the principal-agent problem between managers and their shareholders.

The identified weaknesses in corporate governance of banks in Nigeria included disagreements between board and management giving rise to board squabbles; ineffective board oversight functions; fraudulent and self-serving practices among members of the board, management and staff. (CBN, 2012). There are also limited studies (Kleffner et al., (2003; Paape \& Spekle, 2011) that tested the influence of regulatory environment on the adoption of ERM but these studies were not conducted in the banking sector. Therefore, the principal objective of this study is to evaluate the relationship between corporate governance and ERM adoption. The Nigerian banking sector was selected as a context for the study because the banks tend to be quite larger institutions, 
mostly public listed companies, have more complex operations and processes, with considerably larger numbers of stakeholders, and are under strict public scrutiny than enterprises in other sectors. Thus, it is usually expected that banks are more likely to use a higher level of ERM practices as enshrined in the Code of corporate governance (Abdullatif \& Kawuq, 2015).

This research has immensely contributed to the literature on ERM adoption and corporate governance. This is the first known study, perhaps to the authors best knowledge, which empirically analysed the relationship between corporate governance and ERM adoption in the Nigerian banking sector. The impact of corporate governance on ERM adoption is put to the test, which is the critical driver of ERM implementation, especially in the Nigerian banking sector. The rest of the paper is organised into sections. The following part is the literature review, followed by the methodology, and then, result and discussion. The conclusion is the last part.

\section{LITERATURE REVIEW}

\subsection{Risk Management}

Risk management is not a new idea as it has been in existence for thousands of years (Bernstein \& Peter, 1996). However, the rise of formal risk management came with its publication in Business Harvard Review in 1956 by Russell Gallagher. Dickinson (2001) notes that in the 1970s, business enterprises started exploring how best to manage the various financial risks such as changes in interest rates, exchange rates, stock prices and commodity prices, hence, the development of financial risks management as a formal system. Then, businesses transfer risks related to accidents, human error, fraud and natural catastrophes through insurance companies (Dickson, 2001). The management of these risks is meant to reduce the impact on the business that brought a broader approach to the management of insurable risks. Risk management is a process that involves the system of identifying, evaluating, planning, and managing risks (D`Arcy, 2001). The risk is now managed proactively on the offensive instead of treating it on the defensive that is either minimised or avoided.

\subsection{Enterprise Risk Management}

Sequel to the level of awareness of the limitation of the Traditional Risk Management (TRM) capabilities of the present day business environment, many corporations began to expand their traditional approach to risk management and then, to Enterprise Risk Management (ERM) approach. Enterprise Risk Management is a new approach to risk management which evaluates the mission, vision and strategies of the business (Whitfield, 2003). A transformation from the TRM approach to ERM system is called as a paradigm shift (Hoyt \& Liebenberg, 2006; Manab \& Kassim, 2012). A paradigm shift is a situation whereby companies are moving toward ERM development through the expansion of the risk management concept, methodologies and techniques (KPMG, 2002). Empirical research by Meulbroek (2002) identified the risks that are faced by the firm and affect its performance. These include operational risk, product risk, input risk, financial risk, tax risk, legal risk and regulatory risk. COSO (2004) defines ERM as:

"Process, effected by an entity's board of directors, management and other personnel, applied in strategy setting and across the enterprise, designed to identify potential events that may affect the entity, and manage risk to be within its risk appetite, to provide reasonable assurance of entity objectives" (p. 12). 
The COSO framework emphasises the significance of board`s participation in risk management and, in fact, the decision for its deployment commences at the board level. Nevertheless, another framework that made an impact on ERM positioning is the ISO 31000:2009. This framework contained a systematic process for managing risk. It can be used by any organisation regardless of its size, activity or sector.

\subsection{Corporate Governance}

Kwakwa and Nzekwu (2003) view governance as a "vital ingredient in the balance between the need for order and equality in society; stimulating the efficient production and delivery of goods and services; ensuring accountability in the reams of power and the protection of human right and freedoms". Governance is, therefore, concerned with the processes, systems, practices and procedures that govern institutions, the manner in which these rules and regulations are applied and followed, the relationships created by these rules and nature of the relationships. Corporate governance, on the other hand, refers to the manner in which the power of a corporate is exercised in accounting for corporation's total portfolio of assets and resources with the objective of maintaining and increasing shareholder value and the satisfaction of other stakeholders while attaining the corporate mission (Kwakwa \& Nzekwu (2003).

Magdi and Nadereh (2002) emphasise that corporate governance connotes ensuring that the business is appropriately managed and investors receive a fair return. OECD (1999) provides a more encompassing definition of corporate governance. It defines corporate governance as the system by which business corporations are directed and controlled. The corporate governance structure specifies the distribution of rights and responsibilities among different participants in the corporation such as, the board, managers, shareholders and other stakeholders, and spells out the rules and procedures for making decisions on corporate affairs. By doing this, it also provides the structure through which the company's objectives are set and the means of attaining those objectives and monitoring performance (Akinsulire, 2006).

\subsection{Empirical Review of Related Literature}

\subsubsection{Enterprise Risk Management in the Nigerian Banking Sector}

The worldwide economic crisis affected the Nigerian economy in some ways: The economy has had some external and internal shocks in recent years, which affected the banking sector. There was a drop in oil prices and followed by currency devaluation in 2008. The drop in oil price has put more stress on the DMBs banks while the Nigeria Stock Exchange (NSE) collapse adversely affected the banks' visibility to marginal lending. The supervisory authorities tightened monetary policy in 2011 after an upsurge in inflation and a deterioration in international reserves in 2010 (CBN, 2010; Owojori et al., 2011). The Central Bank of Nigeria (CBN) is the apex bank and the central regulatory and supervisory authority over the banking sector. At the commencement of the 2008/09 banking crisis, the drastic reforms instituted by the apex bank restored confidence and returned the sector to normalcy (Middle Africa, 2013). A study conducted by Njogo (2012) examined risk management practices in the banking sector of Nigeria and documented that the banking industry is a highly controlled industry with a high level of leverage that is related to high risk. Hence, the banks require a high degree of risk management practices. Therefore, this calls for more intensive and efficient ERM implementation in the banking sector. However, there exist marked differences in the level of ERM implementation across different industries and organisations depending on the driving force for ERM adoption (Ciocoiu et al., 2009). Future studies are therefore needed to test the level of ERM 
implementation in different settings and recognising environmental influences in the choice of variables.

\subsubsection{Relationship between Corporate Governance and Enterprise Risk Management}

Widespread interest in corporate governance, enterprise risk management and bank performance sparked off by the US Sarbanes-Oxley Act (SOX) and the requirement for US-listed companies to put in place and implement appropriate governance controls to ensure compliance with SOX for improving operational decision making and performance, warranted the growing alignment between ERM and corporate governance across the world (Sarens \& De Beelde, 2006). The interconnectivity between corporate governance, ERM, and compliance (GRC) with rules and regulations as it relates to banks are considered as an umbrella word that covers an organisation's approach to managing the relationships between these three concepts. Corporate governance, risk management and bank performance are intimately related concerns which are increasingly being aligned together for assessment and avoid conflicts, wasteful overlaps and gaps in the overall management of the business (COSO, 2004; Gupta \& Thomson, 2006).

The increasing attention devoted to corporate governance and the continuous changing role of the auditors influences the changing response of the internal audit function primarily as it affects ERM (Beasley et al., 2006). This shows a decisive and collaborating role on essential topics of corporate governance that include risk management and internal control. The role of internal auditing is both helpful and practical in strengthening the governance mechanisms (IIA, 2009). In a similar study by Spiral and Page (2003), it is evident that risk management has become a key to corporate governance.

\subsubsection{Stage of Enterprise Risk Management Implementation}

Many corporate governance reform experts have predicted for the worldwide acceptance of an enterprise-wide approach to risk management known as Enterprise Risk Management (ERM). Enterprise Risk Management is different from traditional approaches that concentrate on risk oversight by managing risk in a silo or separate units of risks. Enterprise Risk Management emphasises a top-down, enterprise-wide survey of the portfolio of relevant risk exposures possibly affecting an organisation's ability to achieve its objectives (Beasley et al., 2010). Several studies have examined the adoption of ERM in organisations in different contexts.

Beasley et al. (2005) examine the components linked up with the extent of ERM deployment in 123 US organisations from different industries. The following variables were tested; the presence of a CRO, independence of the Board of Directors, management expectations for ERM, auditor type, establishment size, industry and country of domicile. The findings reveal that board and senior management leadership concerning ERM are critical to the extent of ERM deployment. Nonetheless, the role of the Board of Directors was relegated to the background which calls for further evaluation so as to assess the effect of the board on the determinants and the stage of ERM adoption using other variables.

Furthermore, Desender (2011) evaluated the degree of the ERM implementation in Spanish firms using 2834 Pharmaceutical preparations. The study presented exciting findings, among which are; Pharmaceutical companies were positively related to objective setting and risk identification and risk assessment, while there is a weak relationship between control activities and monitoring. Board independence is only significantly positively related to ERM when there is a separation of CEO and chairman. The scope of Desender's study is restricted to the Pharmaceutical firms and used secondary data to 
assess the extent of implementation of ERM deployment and the effects of the drivers for ERM adoption. Therefore, there is a need to carry out a similar study in other sectors such as the banking sector which requires high-level ERM practices using a survey approach to obtain first-hand information from the real operators of the ERM process across all segments of the entity. Similarly, Hoyt and Liebenberg (2011) review the extent of ERM implementation and its value addition in 275 US insurance. The research offers a beginning spot for additional research into ERM implementation and value addition. The study further finds a positive relationship between firm value and the role of ERM. This study recommends additional research into ERM implementation which forms the basis for the present study.

In the same vein, Paape and Spekle (2011) examined the extent of ERM implementation and the factors that are related to cross-sectional differences in the stage of ERM adoption. The work also examined specific ERM strategic adoptions and their impact on perceived ERM effectiveness in different industries of the Netherlands. The research adopted a survey approach to collect cross-sectional data from 825 organisations while applying the Logistic Regression Model (LRM) for data analysis. The study found that the extent of ERM implementation is influenced by the regulatory environment, internal factors such as $\mathrm{CRO}$ and RMC, ownership structure, and firm and industry-related characteristics. Hence, such studies need to be conducted in developing economy such as Nigeria given the different regulatory regimes and corporate governance practices.

Accordingly, Manab et al. (2010) further tested the drivers for the success of EWRM implementation with corporate governance, compliance and value creation in for-profit companies. The study finds that EWRM concepts and its exploits have become a rising concern among Public Listed Companies (PLCs) in Malaysia. From the survey, it is evident that financial companies cited that their EWRM practices were due to corporate governance, compliance, and honest business practice and also for improved decision making. A similar study is required in Nigeria to test the relationship between corporate governance and ERM deployment.

\subsection{Theoretical Framework}

The theoretical framework for this study focuses on the relationship between the independent variables and the dependent variables. The stage of ERM implementation is the dependent variable while the regulatory influence, internal audit effectiveness, human resource competency, top management commitment and board characteristics are the independent variables. Several theories have been used to provide plausible explanations to the concept of ERM. They include Agency theory (Daud, Haron,, \& Ibrahim, 2011; Desender, 2007); Decision theory (Aebi, Sabato, \& Schmid, (2012); Contingency theory (Hudin \& Hamid 2014; Wawera \& Kisaka, 2013); System thinking theory (O'Donnell, 2005); and Institutional theory (Hudin \& Hamid, 2014; Hines \& Peters, 2015). However, the underpinning theory and the supporting theory for this study are Agency and Institutional theories respectively.

It is noted that all the reviewed studies failed to examine the relationship between corporate governance and ERM adoption and the role of Board characteristics in ERM deployment. This has created a severe gap in the literature that warrants big frontiers for further research to address this unwarranted lapse. The present study is aimed at aligning corporate governance with ERM adoption in the Nigerian Commercial Banks using some variables such as regulatory influence, internal audit effectiveness, top management commitment, human resource competency and board characteristic as independent variables while staging of ERM implementation proxy by ERM adoption. The selection of 
the variables was based on literature and contemporary issues in the Nigerian banking sector.

\section{RESEARCH METHODS}

The study adopted a quantitative method using a survey approach. Cross-sectional data was collected through questionnaire. Stratified random probability sampling was employed to determine the sampling frame. The respondents were further stratified into the top, middle and lower level management. The questionnaires were administered to the staff of the 21 banks in three hundred and sixty-one (361) branches across the country and the respective headquarters of the banks. The respondents included the staff of the risk management, internal audit and other departments of the twenty-one (21) commercial (Money Deposit Banks, MDB) banks in Nigeria. The procedure adopted in this research elicited high response rate. The questionnaires were distributed in eight cities (Abuja, Bauchi; Enugu, Jos, Kaduna, Kano, Lagos, and Port Harcourt) across the six geopolitical zones of the country. The completed questionnaires were retrieved by the Research Assistants and also to provide high response rate. The Data was keyed into SPSS version 20 for further analysis. SPSS was used for data screening and preliminary analysis while Structural Equation Modelling (SEM) in Stata was applied for the multiple regression analysis.

Research Model: $(1-S E R M)=\beta 0+\beta 1 C F R+\beta 2 D E F+\beta 3 M E A+\beta 4 A P T+\varepsilon$

\section{RESULT AND DISCUSSION}

A total of 722 questionnaires were distributed, out of which 497 questionnaires were returned representing 69 percent. Out of the 497 answered, 435 questionnaires representing 60 percent were found usable while 62 questionnaires were rejected for analysis on the basis of incomplete filling or improper completion. According to Nakpodia, Ayo and Adomi (2007), the response rate for survey research in Nigeria is 45-73 percent. Therefore, a response rate of 60 percent is considered adequate for the analysis of the current study.

\subsection{Stage of ERM Implementation}

The percentage of ERM complete in place was $89 \%$, while ERM partial in place represents $11 \%$. This shows that there is a significant level of compliance with the CBN directive on ERM implementation. This confirms significant relationship exists between corporate governance and ERM deployment. The result is presented in Table 1.

Table 1. Stage of ERM Implementation (SERM)

\begin{tabular}{lccc}
\hline Stage of ERM & Frequency & Percent & ERM Status \\
\hline ERM Partial in place & 49 & 11 & Partial \\
ERM Complete in place & 386 & 89 & Complete \\
\hline Total & 435 & 100 & \\
\hline ERM Complete in place $=1$ : ERM Partial in place $=0$ & & &
\end{tabular}

\subsection{Correlation Analysis}

Table 2 presents the correlation between the variables. Nevertheless, these coefficients are below the benchmark of 0.7 given by Bryman and Cramer (2005) and unlikely to lead to multicollinearity. The independent variables were not highly correlated. The study also 
used variance inflation factors (VIF) to test for multicollinearity as reflected in Table 3. Once and for all, in that respect there is no multicollinearity problem among the independent variables.

Table 2. Correlation

\begin{tabular}{lccccc}
\hline Construct & $\mathbf{1}$ & $\mathbf{2}$ & $\mathbf{3}$ & $\mathbf{4}$ & $\mathbf{5}$ \\
\hline Top management commitment & 1.000 & & & & \\
Human resource competency & .393 & 1.000 & & & \\
Regulatory influence & .434 & .209 & 1.000 & & \\
Board characteristics & .284 & .274 & .137 & 1.000 & 1.000 \\
Internal audit effectiveness & .443 & .313 & .422 & .188 &
\end{tabular}

Table 3. Multicollinearity Test

\begin{tabular}{lccc}
\hline Construct & Coding & Tolerance & VIF \\
\hline Internal audit effectiveness & IAE & 0.754 & 1.327 \\
Human resource competency & HRC & 0.804 & 1.244 \\
Top management commitment & TMC & 0.749 & 1.335 \\
Regulatory influence support & RIS & 0.591 & 1.691 \\
Board characteristic support & BCS & 0.663 & 1.508 \\
\hline
\end{tabular}

\subsection{Multiple Regression Results using Structural Equation Modeling (SEM) in Stata}

To further confirm the regression results, the hypothesised models are empirically tested using the structural equation modelling (SEM) approach. The Figure 1 and Table 4 show the SEM result of the standardised regression for the Structural Model. The standardised regression estimates depict three direct paths that have a positive and significant relationship with SERM result. However, the direct path values of RIS and BCS are very low, which do not meet the threshold of a minimum of 0.5. Thus, IAE, HRC and TMC have positive relationships while RIS and BCS do not have positive relationships. Those that are positive and significant are; Internal audit effectiveness to stage of enterprise risk management $\beta=0.90$, TV, $7.33 ; p<0.000)$; human resource competency to stage of enterprise risk management $(\beta=1.12$, TV, 7.50; $p<0.000)$ and top management commitment to stage of enterprise risk management $(\beta=0.1 .19, \mathrm{TV}, 7.7 .98 ; p<0.000)$.On the other hand, regulatory influence $((\beta=1.59, \mathrm{TV}, 9.02 ; p<0.000)$ and $(\beta=0.1 .03, \mathrm{TV}, 8.47$; $\mathrm{p}<0.000$ ) while the R2 is $19 \%$.

Table 4: The Stata SEM Result for the Research Model

\begin{tabular}{ccccc}
\hline $\begin{array}{c}\text { Result of Hypothesized } \\
\text { Direct Path }\end{array}$ & $\begin{array}{c}\text { Standardized Regression } \\
\text { Estimate }\end{array}$ & $\boldsymbol{\beta}$ & TV & P \\
\hline H1 & IAE--> SERM & 0.90 & 7.33 & 0.00 \\
H2 & HRC--> SERM & 1.12 & 7.50 & 0.00 \\
H3 & TMC--> SERM & 1.19 & 7.98 & 0.00 \\
H4 & RIS--> SERM & 1,59 & 9.02 & 0.00 \\
H5 & BCS--> SERM & 1.03 & 8.47 & 0.00 \\
\hline
\end{tabular}




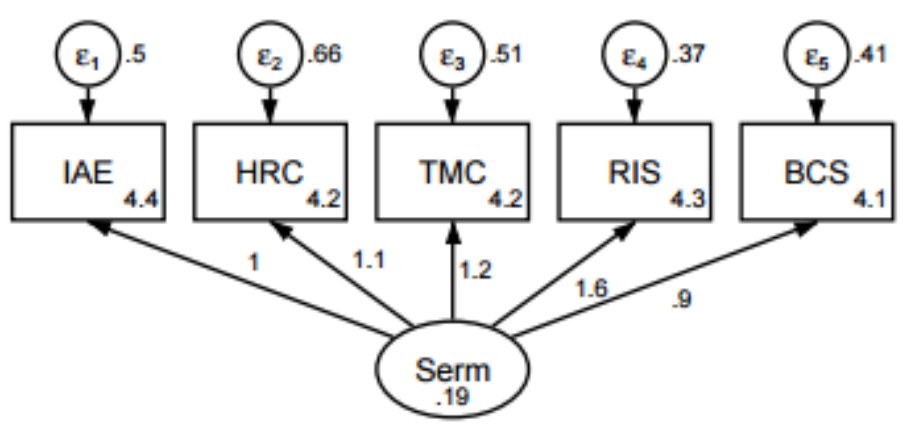

Figure 1: Structural Equation Model

\subsection{Discussion of Findings and Implication}

A critical appraisal of the results in Figure 1 and Table 4 indicate that Internal Audit Effectiveness (IAE), Human Resource Competency (HRC) and Top Management Commitment (TMC) are positively significant hence all the hypotheses for IAE, HRC and TMC are therefore supported. On the other hand, regulatory influence is positively insignificant (RIS) while board characteristics are negatively significant, hence the two hypotheses were not supported.

Descriptive statistics were also used to determine the stage of ERM adoption in the Nigerian commercial banks. From the descriptive statistics, the finding suggests that the Nigerian commercial banks have complete ERM in place because a more significant portion of the respondents confirmed this. This means that there is a high degree of conformity with the CBN directive on the carrying out of ERM in all the commercial banks in line with the Code of corporate governance. This has established a strong relationship between corporate governance and ERM adoption. The result of this survey is confirmed by the finding of a survey conducted in Malaysia by Soltanizadeh, Rasid, Golshan, Quoquab and Basiruddin (2014). Nevertheless, the finding of the study is contrary to the result obtained by Razali et al. (2011) who found 29.7 percent had wholly adopted ERM while 70.3 percent did not implement ERM. The variance in the findings of the two studies was likely due to their approaches to corporate governance.

Structural Equation Modelling in Stata was employed to run the Multiple Regression Model to test the alliance between corporate governance and ERM adoption. The independent variable, corporate governance was proxy by regulatory influence, internal audit effectiveness, human resource competency, top management commitment and board characteristics. The SEM findings show that IAE, HRC and TMC have a positive and significant relationship with the stage of ERM adoption which signifies a strong relationship between corporate governance and ERM adoption. This finding is in agreement with Perrin (2002) which indicates that the application of an ERM framework, especially in the initial phase of implementation requires substantial financial backing from the Board of Directors and top management.

The government has provided the regulatory mandate through the Code of corporate governance by the CBN, but the choice of a framework was voluntary for other sectors (Amran \& Akpan, 2014). This finding is in line with the results of several surveys that find an ERM framework which was a product of corporate governance linked with ERM implementation (Colquitt et al., 1999; Manab et al., 2012). Additionally, Manab and Kassim (2012) found that ERM framework is associated with enhancing shareholder value which is the ultimate goal of corporate governance.

There is plausible evidence that the underpinning theory which is the agency theory substantially explained the impact of the antecedents on the stage of ERM 
implementation. These results provide credible evidence that the type of relationship between the principal and the agent in agency theory may not be the same for non-western culture in developing countries like Nigeria, in comparison to what is obtainable in the western culture and developed nations. As anticipated, the findings revealed that the Model, which is adequately defended by the theories, fits the empirical data. To this end, it can be reasoned that the findings of the research justified the underpinning theories employed and the theoretical model.

\section{CONCLUSION}

This study contributes to the body of knowledge and understanding of the relationship between corporate governance and ERM adoption to stimulate bank performance and enhance shareholders value. The finding revealed that there is an ERM complete in place in the Nigerian banks because the only insignificant percent of the respondents indicated ERM partial in place. This implies that there is full compliance with the CBN Code of Corporate Governance concerning ERM implementation. Further findings revealed that internal audit effectiveness, human resource competency and top management commitment have positive relationships with the stage of ERM adoption in the Nigerian banks which shows significant relationship with corporate governance. Despite the numerous contribution of this work to the body of knowledge, there is a major limitation concerning the measurement of the dependent variable which is dichotomous and the use of other corporate governance variables. Future research is needed to consider examining the stage of ERM implementation in the Nigerian banks using more robust scales such as interval or ratio to overcome such limitation. It is therefore recommended that all levels of banks should adopt ERM practices irrespective of their status.

\section{REFERENCES}

Abdullatif, M., \& Kawuq, S. (2015). The role of internal auditing in risk management: evidence from banks in Jordan. Journal of Economic and Administrative Sciences, 31(1), 30-50.

Aebi, V., Sabato, G., \& Schmid, M. (2012). Risk management, corporate governance, and bank performance in the financial crisis. Journal of Banking \& Finance, 36(12), 3213-3226.

Afolabi, A., \& Dare, A. M. (2015). Corporate Governance in the Nigerian Banking Sector: Issues and Challenges. European Journal of Accounting Auditing and Finance Research. 3(5), 6489.

Akpan, E. O., \& Amran, N. A. (2014). Board characteristics and company performance: Evidence from Nigeria. Journal of Finance and Accounting, 2(3), 81-89.

Beasley, M. S., Clune. R., \& Hermanson, D. (2006). The impact of enterprise risk management on the internal audit function. DigitalCommons@ Kennesaw State University, USA.

Beasley, M., Branson, B., \& Hancock, B. (2015) Report on the current state of enterprise risk oversight: Update on trends and opportunities. 6th Edition, February 2015. The ERM Initiative at North Carolina State University, Raleigh, NC. www.erm.ncsu.edu, Retrieved August 2015.

Bryman, A., \& Bell, E. (2015). Business research methods. Oxford university press. The United Kingdom.

CBN. (2012). Exposure draft code for banks in Nigeria. Central Bank of Nigeria, 2012.

Ciocoiu, N., Dobrea, C., \& Berea, G. (2009). Improving organisation performance through risk management in order to survive a crisis period. Review of International Comparative Management, 4(1), 481-488.

Code of Corporate Governance for Listed companies, (2011) by the Security and Exchange Commission, Nigeria.

COSO (2004).Committee of Sponsoring Organizations of the Tread way Commission. The (COSO, 2004). Enterprise risk management-integrated framework: executive summary, USA. 
Dabari, I. J., \& Saidin, S. Z. (2014). A theoretical framework on the level of risk management implementation in the Nigerian banking sector: The moderating effect of top Management support. Procedia-Social and Behavioral Sciences, 164(1), 627-634.

Dabari, I. J., \& Saidin, S. Z. (2016). A Moderating role of Board Characteristics. International Journal of Economics and Financial Issues. 6(S4), 96-103.

Daud, W. N. W., Haron, H., \& Ibrahim, D. N. (2011). The role of the quality board of directors in enterprise risk management (ERM) practices: Evidence from binary logistic regression. International Journal of Business and Management, 6(12), 205-211.

Desender, K. A. (2011). On the determinants of enterprise risk management implementation. Enterprise IT governance, business value and performance measurement, Nan Si Shi and Gilbert Silvius, eds., IGI Global. De Vaus, D. (2013). Surveys in Social Research, Routledge.

Fadun, O. S. (2013). Risk management and risk management failure: Lessons for business enterprises. International Journal of Academic Research in Business \& Social Sciences, 3(2), 225-239.

Hines, C. S., \& Peters, G. F. (2015). Voluntary risk management committee formation: Determinants and short-term outcomes. Journal of Accounting and Public Policy, 34(3), 267290.

Hoyt, R. E., \& Liebenberg, A. P. (2011). The value of enterprise risk management. Journal of Risk and Insurance, 78(4), 795-822.

Hudin, N. S., \& Hamid, A. B. A. (2014). Drivers to the implementation of risk management practices: A conceptual framework. Journal of Advanced Management Science, 2(3), 163-169.

Jensen, M. C., \& Meckling, W. H. (1976). Theory of the firm: Managerial behaviour, agency costs and ownership structure. Journal of Financial Economics, 3(4), 305-360.

Manab, N. A., \& Kassim, I. (2012a). A moderating effect of leadership on the success of enterprisewide risk management practices. In Proceedings of the 3rd International Conference on Business and Economic Research (3rd ICBER 2012) Conference, Bandung, Indonesia.

Manab, N. A., Kassim, I., \& Hussin, M. R. (2010). Enterprise-wide risk management (EWRM) practices: between corporate governance compliance and value. International Review of Business Research Papers, 6(2), 239-252.

Nakpodia, E. D., Ayo, B. T., \& Adomi, E. E. (2007). A better response rate for questionnaires: Attitudes of librarians in Nigerian University Libraries. Library Philosophy and Practice, 9(2), 50-56.

Njogo, B. O. (2012). Risk management in the Nigerian banking industry. Kuwait Chapter of Arabian Journal of Business and Management Review, 1(10), 100-109.

Owojori, A. A., Akintoye, I. R., \& Adidu, F. A. (2011). The challenge of risk management in Nigerian banks in the post-consolidation era. Journal of Accounting and Taxation, 3(2), 23-31.

Paape, L., \& Speklè, R. F. (2011). The adoption and design of enterprise risk management practices: An empirical study. European Accounting Review, 21(3), 533-564.

Razali, A. R., Yazid, A. S., \& Tahir, I. M. (2011). The determinants of enterprise risk management (ERM) practices in Malaysian public listed companies. Journal of Social and Development Sciences, 1(5), 202-207.

Soltanizadeh, S., Rasid, S. Z. A., Golshan, N., Quoquab, F., \& Basiruddin, R. (2014). Enterprise risk management practices among Malaysian firms. International Conference on Accounting Studies 2014, ICAS 2014, 18-19 August 2014, (pp. 332-337), Kuala Lumpur, MalaysiaProcedia-Social and Behavioral Sciences.

Spira, L. F., \& Page, M. (2003). Risk management: the reinvention of internal control and the changing role of internal audit. Accounting Auditing \& Accountability Journal, 16(4), 640-661. 